\title{
Public Auditors and Detection of Corruption in Nigeria
}

\author{
${ }^{1}$ OSAGIODUWA Lucky Ogbomo, ${ }^{2}$ OKEKE, Stella Ehis, ${ }^{3}$ OHIDOA Toluwa \\ ${ }^{I}$ Department of Accounting, Lighthouse Polytechnic, Evborbanosa, Edo State, Nigeria. \\ corresponding author:osaslucky4321@yahoo.com \\ ${ }^{2}$ Department of Accountancy, University of Nigeria, Enugu Campus, Enugu, Enugu State, Nigeria, \\ ${ }^{3}$ Department of Accounting, University of Benin, Benin, Benin City Nigeria.
}

\begin{abstract}
The study investigated over the years the need and urgency of the auditors in detecting and reporting corruption in the Nigerian public sector. The main objective of this research is to show through empirical analysis that it is the duty of the auditors in detecting corruption in the public sector. The study was conducted in Edo and Delta states of Nigeria. Survey design was employed in the study. The survey was in two folds. In 2014, copies of questionnaires were distributed to accountants and auditors in the public sector and 5 audit firms. A total of 117 copies of questionnaire were retrieved. While in 2018, a similar copy of questionnaire was distributed to auditors only, working in the public sector in the two states. The Systematic Random Sampling Technique (SRST) was used in selecting 62 respondents from a population of 484 in 2018. The bio data and analysis was done using the Simple Percentage Analysis. The findings revealed that corruption detection by the auditors should be part of auditor's role and exposure of corruption by the auditors will reduce corruption in the public sector in Nigeria. The study therefore recommends that ISA 200 and other Auditing standard should be reviewed to incorporate detection and reporting of corruption as key auditors' responsibility. The State and National Houses of Assemblies should enact Act to review and impute the expected role of the auditors in the light of increasing accountability to the public.
\end{abstract}

Keywords: Corruption, Detection, Exposure, Auditors, Reporting

\section{Introduction}

Assertion that it is the auditor's responsibility for the detection, prevention, and reporting of corruption, other illegitimate operation and activities is one of the main controversial and contentious issues in auditing. Importantly, it has become one of the most repeatedly debated areas in the midst of auditors, media, politicians, regulators and the public (Gay et al 1997 cited in Oyinlola 2010). The debate has been particularly highlighted by the liquidation of both undersized and gigantic corporations across the world. Auditing profession in Nigeria has caught the media's attention following fiscal indignity in a number of the Nigerian banks such as Afribank, Intercontinental Bank, Oceanic Bank, and Bank PHB among others(Oyinlola 2010).

Looking back to history, Alleyne and Howard (2005) opined that the auditor's role in the beginning was not well defined and definite. Meanwhile, Idris (2009) noted firmly that there seems at the moment to be a misconception that auditors' responsibilities are principally the preventing, detecting and reporting of corruption. Meanwhile, De Paula and Attwood (1976) cited in Mohammad, Fatemehm, Vahid, and Maziyar (2011) believed that external auditing can be used to detect financial irregularities. While ISA 200 provided that it is not the role and responsibility of auditors to detect fraudulent and corrupt activities in either public or private sector.

Furthermore, Standing and Vuuren (2003) opined that auditors examine client's financial record and should detect any irregularities in their business turnover; several might want to see auditors as the primary line of protection against money laundering. Regrettably, it seems that auditors conducting general audits are not looking for evidence of this type of crime as it is outside the scope of general audits. None of these factors that undermine auditors reporting suspected cases to the authorities are insurmountable (Standing \& Vuuren, 2003). However, Kimbro(2002) undoubtedly noted that external auditing serves as a monitoring mechanism to check on the accuracy of financial information, and to prevent and to discourage financial misappropriation. Law makers may decide to guard auditing firms from being sued if they wrongfully accuse a client of money laundering, the efficiency of law enforcement can 
be improved to the point that auditors feel confident in reporting cases, and there may be merit in awarding auditing companies a monetary recompense for successfully reporting an instance of corruption, and so on. Besides, auditing firms have the potential to instruct their clients in order to make it less easy to embezzle money through their business, which in turn restrict their client's exposure to inadvertently financial theftand corrupt act that could have devastating consequences for the business involved (Standing \& Vuuren, 2003).

The aim of this paper is to identify public accountants and auditors perceptions of the necessity of corruption detection and exposure to the 'shareholders' (public) by auditors in the Nigerian public sector, and to determine their perceptions of the auditors' responsibilities in detecting fraud and the performance of related audit procedures. The paper also aims to ascertain whether the public accountants and auditors perceptions of auditors' responsibilities on corruption detection and exposure are consistent over the years. Only very few related study is available on this subject. Oyinlola (2010) did a similar study but he focused his study in the private sector. Hence, it is therefore necessary to carry out a study in the public sector. Corruption to this study is probably the theft of public fund for personal use. The broad objective of this paper is to prove beyond doubt whether or not it is the role of auditors in detecting corruption in the public sector.

\section{Objectives of the study}

1. To determine the extent to which detection of corruption should be a component of auditor's responsibility in the public sector in Nigeria.

2. To ascertain the extent to which corruption exposure by the auditors to the public will reduce corruption in the public sector in Nigeria.

\section{Literature review}

\section{Corruption}

As documented by Machiavelli (cited in Otalor \& Eiya 2013) defined corruption as a practice by which the good worth of the citizen is damaged and eventually destroyed. They further argued that man had been corrupted by social and political life. It is not the corruption of man which destroyed the political system but the political system which corrupts and destroys man. To Myint (2000), corruption is the use of public office or the use of official position, rank or status by an office bearer for his own personal benefit. Similarly, Enweremadu and Okafor (2009) and Vian, Brinkerhoff, Feeley, Salomon, and Nguyen, (2012) opined that corruption is the mismanagement of public power, resources, and office for private or personal gains. In the same vein, Brooks (1910) cited in Osagioduwa (2019) defined corruption as the calculated misconduct or abandonment of a recognised duty or the unwarranted exercise of power, with the intention of gaining some benefit more or less directly personal. However, Simon (about 56 AD) considering the effect of corruption noted in his writing to the Galatians that he that sow to his flesh (personal gain) shall of the flesh reap corruption; but he that sow to the Spirit shall of the Spirit reap life everlasting.

\section{Imperativeness of Auditors' Independence in Corruption Exposure}

Oladipupo (2005) defined an auditor as an independent expert assigned to assess and examine an organization's financial records and financial statements prepared by them and form his opinion on the true and fairness of the financial statements. Technically, an auditor should be a member of a recognised professional body of accountancy who is into public practice. Millichamp (1990) cited in Akpomi and Amesi (2009) emphasize that a vital ingredient of auditing is that the auditormust be independent of the management and organization whose accounts and books he is auditing. When auditing companies, the auditor should and must not be associated with either the directors or the shareholders. The auditor must also be independent of government and its agencies or other groups who have interest in the organization. For these cause auditors often form themselves into independent firms willing to execute audit for a fee for whoever is able, ready, and willing to engage them. However, Howard (1982), in his opinion opines that for auditors to be really independent the auditor should not have personal interestin terms of investment either physically or otherwise in the organization the auditor is auditing. Meanwhile, if an auditor has interest of any sort in the organization he is auditing, there will be no independence of any kind and the Stakeholders or Members of the Board of Directors have to dictate to the auditors what they will do, thereby losing the pride of independence in an auditor (Howard, 1982). It is not unlikely that an auditor whose independence had been compromised will lack the courage and integrity of mind to report fraudulent practices discovered in the course of the audit engagement. It 
is probable therefore that an auditor need to be independent in mind and in appearance for him to report base on fact and findings.

Furthermore, Abadi (2005) reiterates that for an auditor to be independent, he should not be interested in anything either financial or material benefit of the organization heis auditing. When this happens it means the auditorhas the right to actually carry out investigations as it is required of him in the profession. In the same vein, Millichamp (1990)in Modugu, Ohonba, andIzedonmi(2012), who argued that, the auditor should be independent and he should not grant loan or receive loan from his client. A similar prohibition is on the guarantee of individuals' partners; their spouses and their minor children should also not make loans or guarantee loans toclients nor receive loans or guarantee from clients. It is pertinent to say that for auditors to act independently, they should avoid professional relationships where personal relationship also exists (Modugu, Ohonba, \&Izedonmi 2012). To Khan(2006), the starting point for corruption auditingis that the auditors should cling on to the traditional supposition about the behaviour of the staff with respect to organization's business and should not commence audit planning with the suspicion of corruption.

Corruption can be exposed largely and traditionally by the auditor via the audit report. The audit reports are classified into; Unqualified Opinion. The Unqualified Opinion is a good report. Unqualified opinions signify that the information obtainable in a company's financial report is clean. The audited financial statements can be supposed to be free from misstatements. Qualified Opinion. An view expressed in a qualified audit report is analogous to an unqualified opinion; nevertheless, the auditing body cannot express an unqualified opinion for a number of reasons. One reason could be that the company did not present its financial records in agreement with GAAP.Adverse Opinion. When an auditor gives an adverse report, it reveals that there has been a gross misstatement, fraud, in the preparation of the financial records. Financial statements with adverse audit opinions are typically rejected by financial institutions or investors. Disclaimer Opinion. Auditors give a disclaimer when they could not express a specific opinion. This can be due to the short of accurately maintained financial account or the lack or insufficient support from the management. For example, an auditor may not have had the opportunity to fulfill tasks that they deem to be crucial to the audit, such as observing operational procedures or reviewing particular procedures. (D \& V Philippine nd)

Samuel (2016) noted that the constitution disallows the Auditor-General (AG) from auditing the accounts of "government statutory corporations, commissions, authorities, agencies, together with all individuals and organization created by an Act of the National Assembly." Consequently, the Office of the AG for the Federation cannot audit the financial statements of parastatal, even though it can assume periodic checks in such state owned entities. The mandate of the Office of the AG for the Federation is also restricted to the audit of Federal bodies. Very Importantly, Samuel (2016) posed that each of the 36 states of Nigeria has two Auditors-General, one for the audit of state organizations and the other for the audit of local governments in the state. Altogether, there are 73 AGs in Nigeria, more than the total of Africa combined. However nothing in the present legislation precludes the AG for the Federation from tracing Federal public monies to any state of the Federation. In line with the powers under the Constitution, in 2008 the Office of the AG for the Federation commenced yearly audits of the Federation Account. This account receives oil and other revenue which belong to the 3 tiers of government. These audits have reported a lot of interesting revelations and observations which are now before the National Assembly. The Constitution does provide reasonably strong provisions over the appointment and possible dismissal of the Auditor-General, similar to the provision for appointment and removal of the Chief Justice of the Federation (Samuel 2016). 


\section{Current procedure in Nigerian public sector auditing}

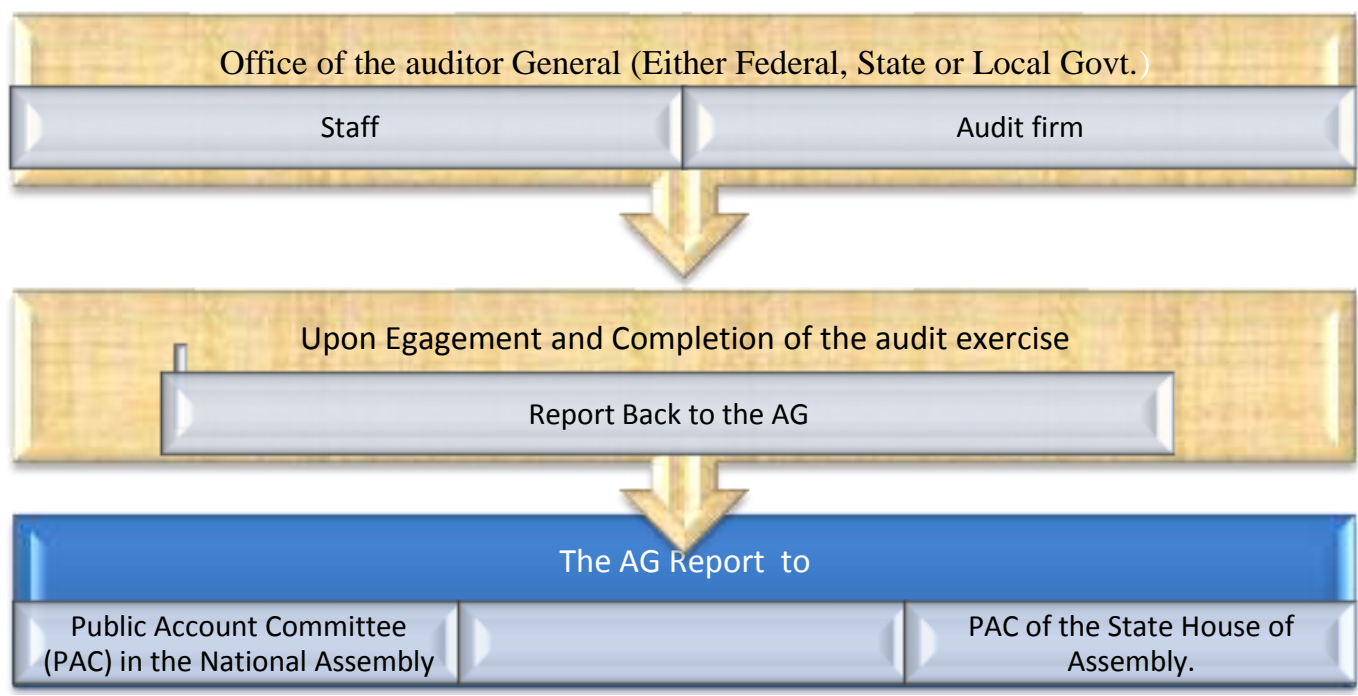

Source (Author)

Fig 2.1 Current procedure in Nigerian public sector auditing

Traditionally, in the Nigerian public sector, the auditors upon the completion of the audit engagement usually by the AG, the auditors reports back to the AG. The Auditor-General for/of the Federal, State and Local Government respectively report without likely investigation to the Public Account Committee. Pius (2017) commented that Public Account Committee PAC is a committee in the National and State Assembly. Order 8 Rule 97(5) of the senate standing law2007 state that there shall be a Public Account Committee established at the commencement of every senate. The functions are to; one, examine the account showing the correctness of the sum approved by the senate together with the audit report. Two examine the report of statutory corporation and boards. Three, enquire the report of the AG of the Federation with respect to any prepayment, audit query which the Chief Executive had overrule (Pius 2017).

\section{Expected Role of the Auditor in Corruption Exposure}

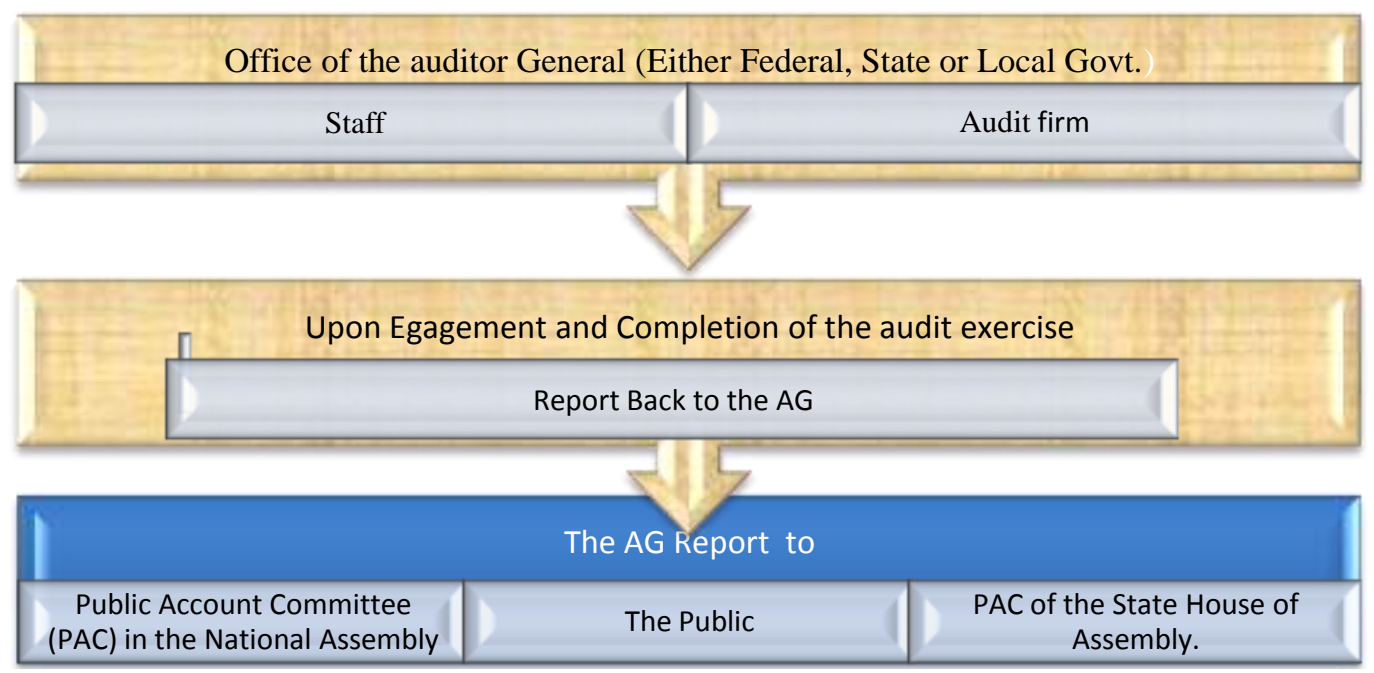

(Source Author) Fig 2.2 Expected Role of the auditor in Corruption Exposure 
In the private sector for instance, the auditor during the usual AGM report to the shareholders the findings during the audit exercise. Due to the likely volume of corruption in the Nigerian public sector, the public are the 'shareholder' in the public sector. Currently, in the Nigerian public sector, it has become necessary for the AG to always give report to the people. This is easy if the report would be published in the newspapers. Nigerians are likely increasing concern about the issue of accountability especially in the Nigerian public sector. Similarly, Agbo and Aruomoaghe (2014) recommended that performance audit report should be made public because it will be a deterrent to others. In the same vein, publishing the report will not only increase accountability and transparency but also make the government more honest and stay away from all forms of fraudulent activities and actions. Furthermore, Akinbuli (2013) and Omodero andOkafor (2016)discovered that the level of accountability is very pitiable in Nigerian public.

In "The Role of Auditors in Fraud Detection, Prevention and Reporting in Nigeria", Oyinlola (2010) examined the role of auditors in the detection, prevention, and reporting of fraud. Data collected from one hundred and eighty-four (184) respondents in Nigeria were used. Respondents were managers, bankers, accountants, and investors. The result revealed that the respondents are very concerned about fraud. In addition, the managers, bankers, accountants, and investors have very high expectation on auditors' roles in prevention and discovery of fraud.

However, Agbo and Aruomoaghe (2014) studied "Performance Audit: A Tool for Fighting Corruption in Nigeria's Public Sector Administration". Primary data were employed in the study. Copies of questionnairewere distributed to government ministries and local government councils in Edo and Delta states. One hundred (100) copies of questionnairewere distributed to staff of these various ministries and local government councils of which ninety-four (94) were properly filled and returned. Pearson's Correlation Coefficient was employed for the analysis. The study revealed that performance audit could be an effective tool in combating corruption in the public sector of Nigeria. It recommended that performance audit report is made public and severe penalty should be melted on any offender to serve as prevention to others.

\section{Theoretical Review}

This study anchors on the agency theory. The agency theory originated in the educational literature in the early 1970s (Jensen \& Meckling, 1976; Ross, 1973; Shapiro, 2005 in Agu, 2016). In the agency relationship, one party acts on behalf of another party. Agency theory emphasis that accountability is indispensable in order to guarantee that the principal-agent problem is reduced (Berle \& Means, 1932 in Agu, 2016). Jensen and Meckling formulated agency theory in 1976. The theory models the affiliation between principal (the public) and the agent (government). An agent is somebody who carries out responsibility on behalf of another person (the principal). Fama and Jensen (1983) in Agu (2016) submitted that the complexity that evolved from the principal-agent association is that it is impossible for principals to identify every role that the agent should perform in every feasible circumstance. The crucial or comprehensive contract is unattainable due to surrounded reasonableness. The problem developing from the principal-agent relationship was worsened by concealing of information (Fama \& Jensen, 1983 in Agu, 2016).

Akinbuli (2010) cited in Appah and Bariweni (2013) noted that the demand and need foraudit was a result of the conflict of interest. The theory is primarily associated with the conflict of interest between the citizens and the government of the country. Added that the citizen been less informed will, therefore, demand sufficient information to monitors the conducts of the government and be better informed. According to Hayes, Schilder, Dassen, and Wallage (1999), they explained that the agency theory could be used to explain the supply side of the audit market. The effectiveness of the auditor to the third party is determined by the probability that the independent auditor will detect fraudulent acts or errors and the auditor's willingness to disclose the fraudulent practices. However, auditors as independent third parties are installed to operate essentially for the interest of the principal and protection of the principal interest from the wrong treatment by its agent. It is of necessity that the third party perform their responsibilities effectively. 


\section{Methodology}

The study employed the survey design. However, the study analyzed data obtained in 2014 and 2018. The Sample size for 2014 was 117 respondents who were only auditors and accountant in Edo and Delta States in Nigeria. 16 public organizations and five audit firms were sampled. In 2018, a similar survey was conducted using the systematic random sampling. The respondents were only auditors in Edo and Delta States. The Population was 484.The sample sizes of one hundred and two 62auditors working in the public sector were chosen. The sample size for the study was calculated using the Okpanachi (2011) (cited in Chigo and Ijeoma, 2017) restructured Yemane (1967) sampling model is employed to justify the sufficiency of the sample size. The formula applied is given as $\mathrm{n}=$ $\mathrm{N} /\left(3+\mathrm{N} \mathrm{e}^{2}\right)$ Where $\mathrm{n}=$ Number of samples, $\mathrm{N}=$ Total population, $\mathrm{e}=$ Error tolerance and $3=$ adjusted constant. The above population is 484 at $7 \%$ significant level for 2018. Linus (2001) considered fifty per cent (50\%) as an adequate response rate for any social science research in Nigeria, which signifies that this research met the response rate demand. Sixty-two (62) copies of filled questionnaire (32 from Edo State and 30 from Delta State) were retrieved.

\section{Chart 4.1 Gender distributions of respondents}

\section{Data Presentation and Analysis}

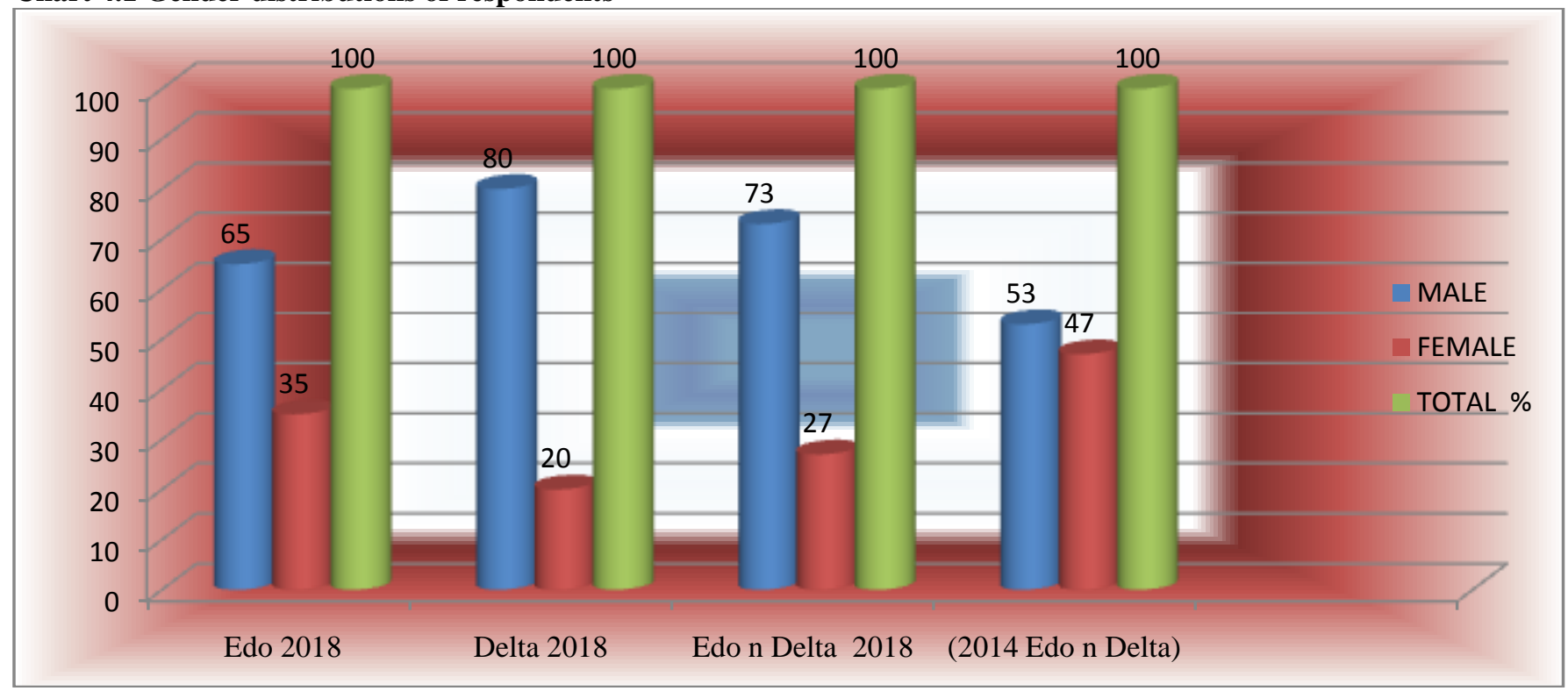

(Field work)

$80.0 \%$ of the auditors sampled in Delta State in 2018 are male while $20.0 \%$ are female. $65.0 \%$ of the auditors in Edo State in 2018 are male while $35.0 \%$ are female. In 2014, male were 53\% while female were $47 \%$ in Edo and Delta state. While in 2018, Male were $73 \%$ while female were $27 \%$.

Table 4.1Years of working experience.

\begin{tabular}{|c|c|c|c|c|c|c|}
\hline & & 14 Edo and Del & & & & \\
\hline $0-5$ years & $6-10$ years & 11-15 years & $16-20$ years & 21-25 years & $26-30$ years & $31-35$ years \\
\hline $44 \%$ & $23 \%$ & $14 \%$ & $8 \%$ & $3 \%$ & $4 \%$ & $4 \%$ \\
\hline & 2018 Edo & & & & & \\
\hline & $2-5$ years & $6-10$ years & $11-20$ years & 21-30 years & Above 30 years & \\
\hline & $17.2 \%$ & $37.9 \%$ & $13.8 \%$ & $24.1 \%$ & $6.9 \%$ & $100 \%$ \\
\hline & & 2018 Delta & & & & \\
\hline & $2-5$ years & $6-10$ years & $11-20$ years & 21-30 years & Above 30 years & \\
\hline & $6.7 \%$ & $26.7 \%$ & $30.0 \%$ & $36.6 \%$ & $0.0 \%$ & $100 \%$ \\
\hline
\end{tabular}

(C) 2020, IJSMS

Page 54 


\begin{tabular}{|c|c|c|c|}
\hline \multicolumn{4}{|c|}{2018 Edo and Delta } \\
\hline & $2-5$ years $6-10$ years & $11-20$ years $21-30$ years & Above 30 years \\
\hline & $11.9 \% \quad 32.2 \%$ & $30.5 \%$ & $3.4 \%$ \\
\hline \multicolumn{4}{|c|}{ 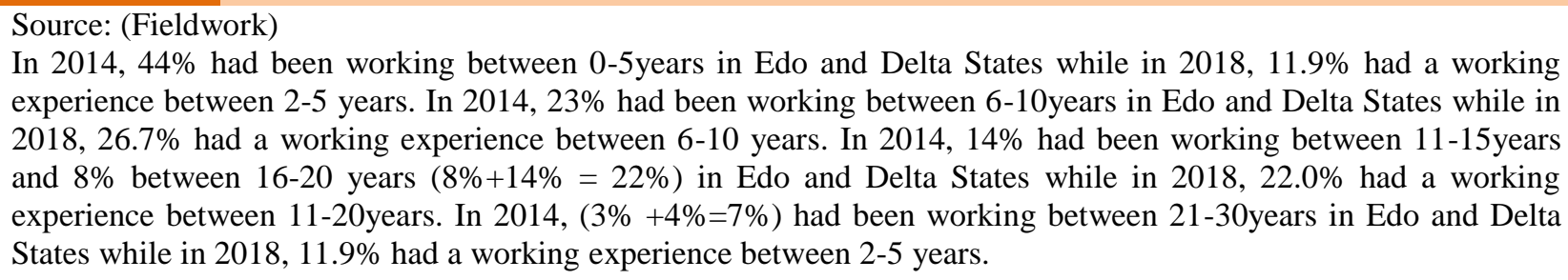 } \\
\hline \multicolumn{4}{|c|}{ Table 4.2 Educational qualification } \\
\hline \multicolumn{4}{|c|}{2014 Edo and Delta } \\
\hline HND & B.Sc & M.Sc & $\mathrm{PhD}$ \\
\hline \multirow[t]{2}{*}{$21 \%$} & $58 \%$ & $6 \%$ & $1 \%$ \\
\hline & 2018 Delta & & \\
\hline NCE/ND & HND/BSC & MSC/MBA & $\mathrm{PhD}$ \\
\hline \multirow[t]{2}{*}{$6.7 \%$} & $70 \%$ & $23 \%$ & $0 \%$ \\
\hline & 2018 Edo & & \\
\hline \multirow[t]{2}{*}{$6.9 \%$} & $79.3 \% \quad 10.3 \%$ & & $0 \%$ \\
\hline & 2018 Edo and Delta & & \\
\hline $6.8 \%$ & $74.6 \%$ & $16.9 \%$ & $0 \%$ \\
\hline
\end{tabular}

Source: (Fieldwork)

In 2014, 6\% of the respondents had MSC while in 2018, 16.9\% of the respondents had MSC. In 2014 and 2018, 0\% of the respondents had $\mathrm{PhD}$ in Edo and Delta States.

Table 4.3 Analysis.

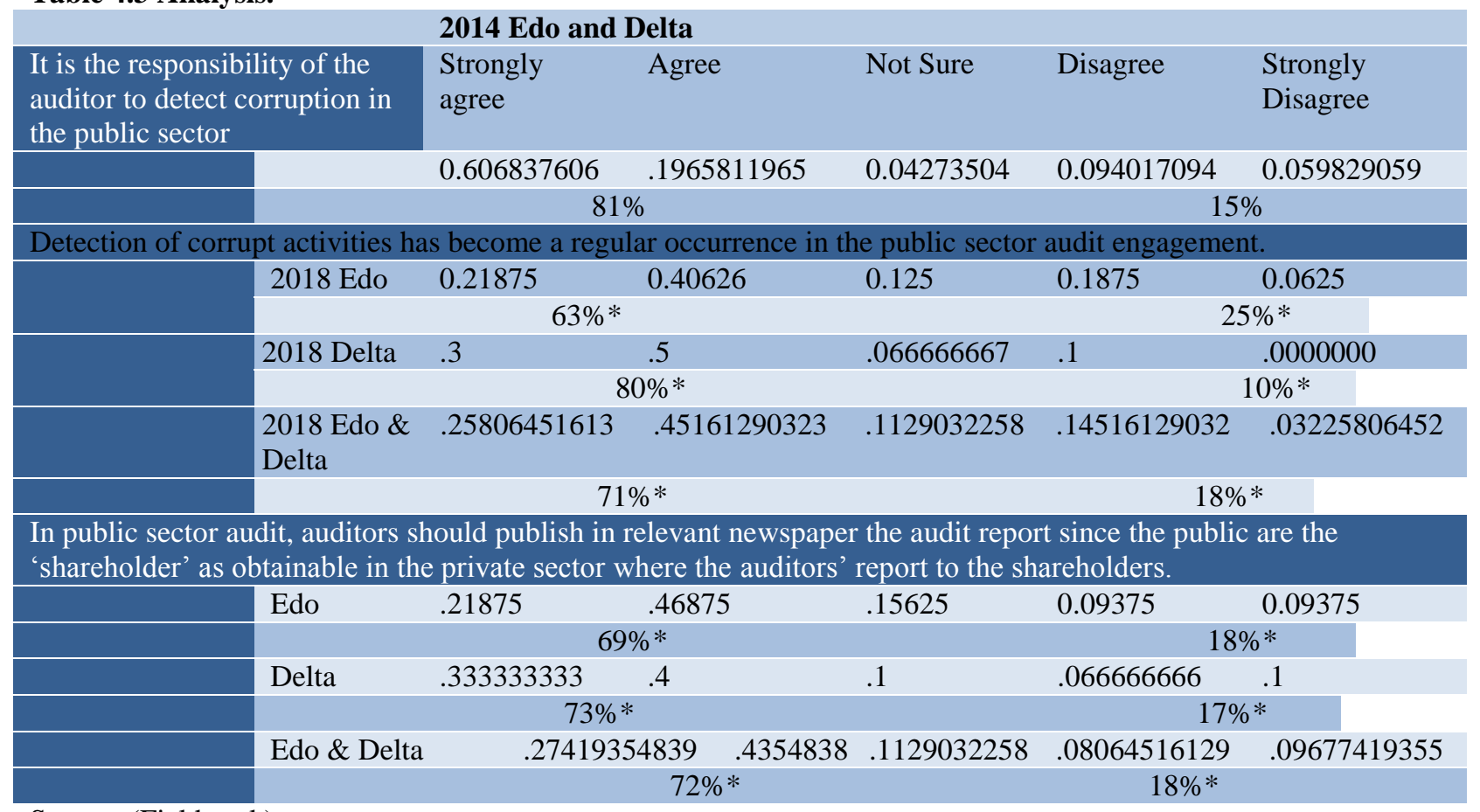

Source: (Fieldwork) 
In $2014,81 \% *$ result revealed that It is the responsibility of the auditor to detect corruption in the public sector. Also, in 2018, 71\%* result further showed that It is the responsibility of the auditor to detect corruption in the public sector. Furthermore, in 2018, 69\%, 73\%*, 72\%* results respectively revealed that in public sector audit, auditors should publish in relevant newspaper the audit report since the public are the 'shareholder' as obtainable in the private sector where the auditors' report to the shareholders.

\section{Discussion, Conclusion, and Recommendations}

ISA 200 provided that i.e it is not the role of auditors to detect fraudulent activities during audit engagement. However, the time series findings of 2010 by Oyinlola, and the above findings of 2014 and 2018 reveals clearly auditors must consider corruption detection as a cardinal role. Eiya and Otalor (2013) noted the auditing profession, as it has evolved, has its roots in the non-government segment where audit against corruption is not a serious concern of the stakeholders who are more concerned with fraud or theft of financial resources and assets. The study therefore concludes that it is the role of the auditors to detect and report corrupt activities specifically in the current Nigerian public sector. Dixon and Wood head (2006) carried out a research on the expectation gap in Egypt. They discovered that many financial statement users believe that the detection of abnormality is a primary audit goal and that the auditors have a duty of detecting fraud and irregularities in order to diminish the incidence in public firms in Egypt.

The study recommends that;

1. The ISA 200 should be reviewed to incorporate detection and reporting of corruption as key auditors' responsibility.

2. The State and National Houses of Assemblies should enact Act to review and impute the expected role of the auditors in the light of increasing accountability to the public.

3. The Auditors General for the Federation and that of the states and local government should issue statements and guidelines to foster and enable this responsibility.

4. The Accounting Professional bodies like the ANAN and ICAN should raise standards that will strengthen and include these responsibilities.

\section{REFERENCES}

[1] Agbo, S., \& Aruomoaghe, J. A. (2014). Performance audit: A tool for fighting corruption in the Nigeria's public sector administrationInternational Journal of Management and Sustainability3(6) 374-383. doi: 10.18488/journal.11/2014.3.6/11.6.374.383.

[2] Agu, S. U. (2016). Instrumentalities for the effectiveness of measures of public accountability in Africa: the Nigeria perspective. 1-11 Doi: 10.1177/2158244015627189 http://www.creativecommons.org/licenses/by/3.0/.

[3] Akinbuli, S. F. (2013). An assessment of accountability in the public sector In Ngeria. Arabian Journal of Business and Management Review (Nigerian Chapter),1(3), 1-11.

[4] Akpomi, M. E. and Amesi, J. (2009). Behavioural constraints on practices of auditing in Nigeria. Educational

[5] Alleyne, P. \& Howard, M. (2005): An exploratory study of auditors' responsibility for fraud detection in Barbados. Managerial Auditing Journal. 20(3), 284-303.

[6] Appah, E., \& Bariweni, B. (2013). An examination of the effectiveness of auditing of local government financial reports in Bayelsa State, Nigeria, Current Research Journal of Social Sciences 5(2), 45-53.

[7] D\&V, Philippine (nd).What happens during an audit? Available from https://www.dvphilippines.com/blog/understanding-audits-the-fourtypes-of-audit-reports.

[8] De Paula, F. C. and Attwood, F. A. (1976). Auditing: Principles and practice. London: Pitman Publishing.December.

[9] Enweremadu, D., \& Okafor, E. (2009). Anti-corruption reforms in Nigeria since 1999: Issues, challenges and the way forward. IFRA Special Research Issue, 3(1), 81-88.

[10] Hayes, R. A., Schilder, R., \& Dassen, W. P. (1999). Principles of auditing: the theory and practice of auditing. Lagos: Gilgal publications. 
[11] Idris, J. (2009): Nigerian Auditors are Toothless Bulldogs. October 3. Available from http://www.saharareporters.com/articles/externalcontrib/3872-nigerias-bank-auditors-are-toothless-bull-dogs.html

[12] Millichamp, A. H (1990). Auditing: An Instructional Manual for Accounting Student: London; 5th Edition DP Publication Limited.Research and Review Vol. 4 (10), pp. 465-469,

[13] Modugu, K., Ohonba, N., \&Izedonmi, F. (2012). Challenges of auditors and audit reporting in a corrupt environment. Research Journal of Finance and Accounting, 3(5), 1-6.

[14] Mohammad A, Fatemeh 1, Vahid S. and Maziyar G. (2011). the role of auditing profession in fighting against economic and Financial crimes. International Conference on E-business, Management and Economics

[15] Myint,U.(2000). Corruption: causes, consequences and cures, Asia-Pacific Development Journal Vol. 7, No. 2,

[16] Oladipupo, A. O. (2005). Auditing and investigation theory and practice. Benin City, Nigeria: Mindex Publishers.

[17] Omodero, C. I., \& Okafor, M. C. (2016). Efficiency and accountability of public sector revenue and expenditure in Nigeria (1970-2014). European Journal of Accounting, Auditing and Finance Research, 4(7), 23-42.

[18] Osagioduwa, L. O, (2019). The effectiveness of the whistle blowing policy in combating corruption in the Nigerian public sector. Global Journal of Arts Humanities and Social Science. 7 (10), 77-98.

[19] Otalor, J. I., \& Eiya, O. (2013). Combating corruption in Nigeria: The role of the public sector auditor.Research Journal of Finance and Accounting, 4(4), 1-11. Available from pakacademicsearch.com/../122-131\%20Vol\%204,\%20No\%204\%20(2013). Pdf.

[20] Oyinlola, A. O. (2010). The role of auditors in fraud detection, prevention and Reporting in Nigeria" (2010). Library Philosophy and Practice (e-journal). Available from http://digitalcommons.unl.edu/libphilprac/517.

[21] Pius S (2017). Corruption : Public Account Committee and legislative oversight. Orderpaper.

[22] Samuel T. U. (2016). Office of the Auditor General of the Federation an introduction and history.

[23] Simon, P. (56AD). King James Bible.

[24] Standing .A \& Vuuren H. v, ( 2003). The Role of Auditors: Research into Organized Crime and Money aundering". Institute for Security Studies. Occasional Paper.

[25] Vian, T., Brinkerhoff, D. W., Feeley, F. G., Salomon, M., \& Nguyen, T. K. (2012). Confronting corruption in the health sector in Vietnam: Patterns and prospects. Public Administration and Development, 32, 49-63. Available from onlinelibrary.wiley.com/doi/10.1002/pad.1607/full. 